Disclosures

\begin{tabular}{|c|c|c|c|c|c|c|c|}
\hline $\begin{array}{l}\text { Writing group } \\
\text { member }\end{array}$ & Employment & $\begin{array}{l}\text { Research } \\
\text { grant }^{1}\end{array}$ & $\begin{array}{l}\text { Other research grant or } \\
\text { medical continuous } \\
\text { education }\end{array}$ & $\begin{array}{l}\text { Speaker's } \\
\text { honoraria }\end{array}$ & $\begin{array}{c}\text { Ownership } \\
\text { interest }\end{array}$ & $\begin{array}{l}\text { Consultant/ } \\
\text { Advisory } \\
\text { board }\end{array}$ & Other $^{3}$ \\
\hline $\begin{array}{l}\text { Thiago Cardoso } \\
\text { Vale }\end{array}$ & UFMG & - & - & - & - & - & - \\
\hline Paulo Caramelli & UFMG & FAPEMIG & - & - & - & - & - \\
\hline $\begin{array}{l}\text { Antônio Lúcio } \\
\text { Teixeira }\end{array}$ & UFMG & $\begin{array}{c}\text { CNPq } \\
\text { FAPEMIG }\end{array}$ & - & - & - & - & - \\
\hline
\end{tabular}

References

1. Ala A, Walker AP, Ashkan K, Dooley JS, Schilsky ML. Wilson’s disease. Lancet. 2007;369(9559):397-408.

2. Machado A, Chien HF, Deguti MM, Cançado E, Azevedo RS, Scaff M, Barbosa ER. Neurological manifestations in Wilson's disease: Report of 119 cases. Mov Disord. 2006;21(12):2192-6.

3. Benhamla T, Tirouche YD, Abaoub-Germain A, Theodore F. The onset of psychiatric disorders and Wilson's disease. Encephale. 2007;33(6):924-32.
4. Shanmugiah A, Sinha S, Taly AB, Prashanth LK, Tomar M, Arunodaya GR, Reddy JY, Khanna S. Psychiatric manifestations in Wilson's disease: a cross-sectional analysis. J Neuropsychiatry Clin Neurosci. 2008;20(1):81-5. 5. Srinivas K, Sinha S, Taly AB, Prashanth LK, Arunodaya GR, Janardhana Reddy YC, Khanna S. Dominant psychiatric manifestations in Wilson's disease: a diagnostic and therapeutic challenge! J Neurol Sci. 2008;266(1-2):104-8.

episodes, ${ }^{1}$ thus suggesting that this group may constitute a refractory sample. Refractoriness is associated with poor treatment outcomes and, therefore, to ceiling effects. ${ }^{2}$ For instance, in the Sequenced Treatment Alternatives to Relieve Depression $\left(\mathrm{STAR}^{*} \mathrm{D}\right)$ study, the cumulative remission rates after one, two, three or four antidepressant trials were $33 \%, 57 \%, 63 \%$ and $67 \%$, respectively. ${ }^{3}$ Sachs et al. aimed at detecting an absolute difference of $15 \%$ between groups, a goal that could hardly be achieved had the subjects presented at least a moderate rate of refractoriness.

2) Strict primary outcomes - the primary outcome of the Sachs et al. study was "durable recovery", defined as eight consecutive weeks of euthymia, with no more than two manic or depression symptoms. This is a more orthodox criterion when compared to the criterion generally applied to most antidepressant trials, which tend to define remission as a mood score $<10$ points, which, in turn, can be translated as the presence of 4 to 5 mild or 2 to 3 moderate symptoms. ${ }^{4}$ When stricter outcome criteria are adopted, both the experimental and the control interventions are more likely to yield similar response rates, thus leading to a ceiling effect.

3) Excessive "noise" - clinical trials are ultimately designed to detect whether treatment effects (the "signal") surpass non-specific effects (the "noise"). In the Sachs et al. study, patients were allowed to increase the dose of the mood stabilizer and enhance the use of pharmacotherapy, psychotherapy, etc. Such factors could have increased the trial "noise" by increasing non-specific effects at the expense of decreasing the "signal" of the experimental treatment.

4) Design issues - Sachs et al. compared mood stabilizer + placebo against mood stabilizer + antidepressant drug. In such type of design, ceiling effects are important since the effect of the combined intervention is weaker compared to the effect of each intervention tested separately. ${ }^{2}$ For example, when two treatments whose individual remission rate is set at $50 \%$ are 
combined, the combined treatment is not likely to lead to full remission $(100 \%)$. To assess an antidepressant's efficacy, which was probably lower in the Sachs et al. study, the study's design should have included a pure placebo arm. The study, however, followed the ethical principle of equipoise, which states that should be genuine uncertainty on the preferred treatment when designing interventional studies. ${ }^{5}$ Therefore, the use of pure placebo arms in pragmatic, phase IV studies is unfeasible due to ethical concerns involving the offering of an inferior treatment for a prolonged period of observation.

In conclusion, given that the number of pragmatic trials in Psychiatry has increased over time, we are now allowed to test the effectiveness of interventions in the "real world". As exemplified by the Sachs et al. study, such trials, however, have certain design characteristics that can lead to ceiling effects. Therefore, when translating results into clinical practice, clinicians should be aware of the possible caveats to be found in pragmatic studies.

Andre Russowsky Brunoni Center for Clinical Research, University Hospital, Universidade de São Paulo (USP), São Paulo, SP, Brazil Department of Neurosciences and Behavior, Institute of Psychology, Universidade de São Paulo (USP), São Paulo, SP, Brazil

Disclosures

\begin{tabular}{|c|c|c|c|c|c|c|c|}
\hline $\begin{array}{l}\text { Writing group } \\
\text { member }\end{array}$ & Employment & $\begin{array}{l}\text { Research } \\
\text { grant }^{1}\end{array}$ & $\begin{array}{l}\text { Other research } \\
\text { grant or medical } \\
\text { continuous } \\
\text { education }^{2}\end{array}$ & Speaker's honoraria & $\begin{array}{c}\text { Ownership } \\
\text { interest }\end{array}$ & $\begin{array}{l}\text { Consultant/ } \\
\text { Advisory } \\
\text { board }\end{array}$ & Othel \\
\hline
\end{tabular}

* Modest

** Significant

*** Significant: Amounts given to the author's institution or to a colleague for research in which the author has participation, not directly to 1 author.

Note: USP = Universidade de São Paulo.

For more information, see Instructions for Authors.

References

1. Sachs GS, Nierenberg AA, Calabrese JR, Marangell LB, Wisniewski SR, Gyulai L, Friedman ES, Bowden CL, Fossey MD, Ostacher MJ, Ketter TA, Patel J, Hauser P, Rapport D, Martinez JM, Allen MH, Miklowitz DJ, Otto MW, Dennehy EB, Thase ME. Effectiveness of adjunctive antidepressant treatment for bipolar depression. $N$ Engl J Med. 2007;356(17):1711-22.

2. Jindal $\mathrm{RD}$, Thase ME. Integrating psychotherapy and pharmacotherapy to improve outcomes among patients with mood disorders. Psychiatr Serv. 2003;54(11):1484-90.

\section{Suicídio em adolescentes no Brasil: problema de saúde publica?}

\section{Suicide among adolescents in Brazil: public health problem?}

Caro Editor,

Em artigo recém publicado, "Ideação suicida em adolescentes de 11 a 15 anos: prevalência e fatores associados", Souza et al. abordaram um assunto muito importante sobre a prevalência $(14,1 \%)$ e fatores associados à ideação suicida entre adolescentes, tais como ser do gênero feminino (principalmente as jovens com vida sexual ativa), sofrer de provável problema mental e uso de substâncias psicoativas ${ }^{1}$. Esta publicação nos leva a considerar algumas questões de saúde pública.
3. Gaynes BN, Rush AJ, Trivedi MH, Wisniewski SR, Spencer D, Fava M. The STAR*D study: treating depression in the real world. Cleve Clin J Med. 2008;75(1):57-66.

4. Gelenberg AJ, Thase ME, Meyer RE, Goodwin FK, Katz MM, Kraemer HC, Potter WZ, Shelton RC, Fava M, Khan A, Trivedi MH, Ninan PT, Mann JJ, Bergeson S, Endicott J, Kocsis JH, Leon AC, Manji HK, Rosenbaum JF. The history and current state of antidepressant clinical trial design: a call to action for proof-of-concept studies.J Clin Psychiatry. 2008;69(10):1513-28.

5. Freedman B. Equipoise and the ethics of clinical research. $N$ Engl J Med. 1987;317(3):141-5.

A primeira questão refere-se à necessidade de conhecimento atualizado e sistematizado sobre a frequência de ideação suicida, a frequência das tentativas de suicídio e, por fim, o número de suicídios completos. A cidade de São Paulo tem 1.628.589 jovens entre 10 e 19 anos, sugerindo uma prevalência de 2/100.000 casos de suicídio nessa população, com maior concentração de suicídio completo entre 15 e 19 anos e com métodos mais violentos (Tabela 1). Porém, não dispomos de dados sobre as tentativas de suicídio, o que seria necessário para delinearmos um cenário mais preciso acerca do risco dessa população e assim estabelecer os planos de ação visando à prevenção.

O segundo aspecto é o reduzido número de pesquisas sobre o desenvolvimento dos transtornos mentais desde a infância e a busca de uma nova metodologia para identificar transtornos mentais e sintomas precoces na população infantil ${ }^{2}$. Nesse sentido, seria fundamental que a Psiquiatria buscasse critérios para a definição de casos "com risco", desenvolvendo metodologias que identificassem estes indivíduos e realizassem intervençōes antes 